\title{
Maxwell v. Superior Court: Buying Counsel of Choice or Ineffective Assistance?
}

In Maxwell v. Superior Court, ${ }^{1}$ the California Supreme Court considered the ethical and constitutional questions raised when a criminal defendant retains an attorney by means of a contract that grants the lawyer the rights to the defendant's life story. Such life story fee contracts create a conflict of interest between a lawyer's financial interests and his professional responsibility to his chent. This tension is especially acute in capital cases like Maxwell, since a sensational trial may both enhance the publication value of the defendant's hife story and endanger the defendant's life. Life story fee contracts also create a conflict between two sixth amendment rights. A criminal defendant has a limited constitutional right to counsel of his choice, but representation by a lawyer with a conflict of interest may violate the defendant's fundamental constitutional right to effective assistance of counsel.

In Maxwell the court permitted the defendant to proceed with the attorneys he retained through a life story contract, holding that the defendant could waive the right to effective assistance of counsel in order to assert his right to be represented by his chosen attorneys despite the conflict of interest. The court reasoned that the "potential conflicts or ethical concerns"2 remaining after the waiver should not prevent the exercise of the right to counsel of choice.

Part I of this Note summarizes the Maxwell facts and opinions. Part II outlines the legal background to the case. Part III argues that the court inadequately balanced the competing interests involved in the case. Part III further contends that the court misjudged the nature of the conflict created by a life story contract, and for this reason underestimated the threat posed to the state's special interest in ensuring effective representation when a defendant faces a possible death sentence. This Note suggests that whenever a defendant's desire to be represented by a particular counsel conflicts with a significant state interest, the court should engage in a balancing process that is more closely tied to the facts of the case. On a case-by-case basis, the court should examine both the objective considerations supporting the defendant's interest in representation by a particular attorney, and the strength of the

1. 30 Cal. 3d 606, 639 P.2d 248, 180 Cal. Rptr. 177 (1982) (en banc).

2. Id. at 622,639 P.2d at 258,180 Cal. Rptr. at 187. 
state's interest. This Note concludes that in this case the state interest in fair proceedings and the integrity of the judicial systein outweighed Maxwell's interest in being represented by his chosen attorneys.

\section{I \\ The CASE \\ A. The Facts}

Eleven residents of Los Angeles' Skid Row were stabbed to death in late 1978 and early 1979.3 The inedia sensationalized the events, calling the killer the "Skid Row Stabber." The police arrested Bobby Joe Maxwell, found in the Skid Row area with a knife in his hand, standing over a sleeping drunk. ${ }^{4}$ Maxwell was charged with inultiple counts of robbery and first degree inurder. Solne counts involved "special circuunstances" that raised the possibility that the death penalty would be imposed. ${ }^{5}$

Maxwell did not want to be represented by a public defender or a court-appointed lawyer, but he was indigent and thus unable to hire his own attorney. He did have one potentially valuable asset: the rights to his life story, including the events of the pending criminal prosecution.

Maxwell entered into a contract in which lie assigned the commercial and publication riglits to his life story to a small law firm im exchange for its agreeinent to represent him. The contract enumerated several conflicts of interest that might arise between Maxwell and his lawyers: first, the lawyers might want to generate publicity harmful to Maxwell; second, they might not raise any psycliological defense that could cast doubt on the validity of the contract; third, they might want Maxwell convicted and even executed in order to generate additional publicity. ${ }^{6}$ The contract stated that the lawyers would not be influenced by these or any unnamed conflicts. It also stated that they would raise every defense that might help Maxwell, and would act as diligent and conscientious advocates for his defense. ${ }^{7}$ The contract encouraged Maxwell to consult another attorney about the arrangement, but he declined to do so. ${ }^{8}$

In separate appearances in municipal and superior court, Maxwell

3. L.A. Times, May 19, 1979, pt. 2, at 1, col. 5, at 12, col. 5.

4. Id. at 1 , col. 5 .

5. $30 \mathrm{Cal}$. 3d at 610,639 P.2d at 249,180 Cal. Rptr. at 179. Section 190.2(a) of the California Penal Code prescribes a penalty of death or life imprisonment without the possibility of parole for first degree nurder when there has been a finding of one of the "special circumstances" enunerated in the statute. Cal. Penal Code $\$ 190.2$ (a) (West 1983).

6. Maxwell contract, para. 14, reprinted in Maxwell v. Superior Court, $101 \mathrm{Cal}$. App. 3d 736, 741-42, 161 Cal. Rptr. 849, 852 (1980), officially depublished pursuant to CAL. CT. R. 976(d).

7. Id.

8. $30 \mathrm{Cal} .3 \mathrm{~d}$ at $611,639 \mathrm{P} .2 \mathrm{~d}$ at $251,180 \mathrm{Cal}$. Rptr. at 180. 
indicated that he understood the potential for conflicts of interest, and stated that he still wanted to be represented by his attorneys. The superior court ruled that the inherent conflicts created by the retainer agreement would violate Maxwell's constitutional right to effective assistance of counsel. The judge then recused Maxwell's lawyers and appointed substitute counsel..$^{9}$ The court of appeal affirmed, ${ }^{10}$ but the Califorma Supreme Court reversed, ordering the superior court to reinstate Maxwell's chosen counsel under the contract. ${ }^{11}$

\section{B. The Opinions}

Writing for the court, Justice Newman stated at the outset that an attorney with conflicts of interest might not satisfy the constitutional guarantee of effective assistance of counsel. ${ }^{12}$ At the saine time, however, effective assistance is closely linked to representation by counsel of choice. ${ }^{13}$ When defendants do not trust their lawyers, "representation may be so undermined as to render it an einpty formality." 14 Thus, while recognizing that the right to counsel of choice is not absolute, the court stated that a judge has very limited discretion to interfere with a defendant's choice in order to eliminate potential conflicts, ensure adequate representation, or serve judicial convenience. ${ }^{15}$

The court acknowledged that life story fee contracts are widely criticized as "inherently prejudicial, unethical, and against public policy," 16 and considered the argument that the state interests im preventing such a contract might possibly outweigh the defendant's interest in representation by his chosen counsel. The court noted that some precedents recognize a judge's power to recuse an attorney to ensure a fair trial and judicial integrity. ${ }^{17}$ But it distinguished these precedents, ${ }^{18}$ reasoning that the state interest was not compelling because the conflict created by the life story contract is not "inherent or inevitable"19 but merely potential. The court did state, however, that a trial court has the power to intervene when an actual conflict nrateriahizes and produces an obviously deficient performance by the lawyer. ${ }^{20}$

The court then affirmed the vahdity of Maxwell's waiver of his

9. Id. at 612,639 P.2d at 251,180 Cal. Rptr. at 180.

10. $101 \mathrm{Cal}$. App. 3d at 756, 161 Cal. Rptr. at 861 .

11. $30 \mathrm{Cal}$. 3d at $622,639 \mathrm{P} .2 \mathrm{~d}$ at $258,180 \mathrm{Cal}$. Rptr. at 187.

12. Id. at 612,639 P.2d at 251,180 Cal. Rptr. at 180.

13. Id. at 613,639 P.2d at 251,180 Cal. Rptr. at 180.

14. Id.

15. Id. at 614,639 P.2d at $252-53,180$ Cal. Rptr. at 181-82.

16. Id. at $616,639 \mathrm{P} .2 \mathrm{~d}$ at $253,180 \mathrm{Cal}$. Rptr. at 182 .

17. Id. at $617,639 \mathrm{P} .2 \mathrm{~d}$ at $254,180 \mathrm{Cal}$. Rptr. at 183.

18. Id. at 618-19, 639 P.2d at 255-56, 180 Cal. Rptr. at 184-85.

19. Id at 618 n.8,639 P.2d at 255 n.8, 180 Cal. Rptr. at 184 n.8.

20. Id. at $619 \mathrm{n} .10,639$ P.2d at $256 \mathrm{n} .10,180$ Cal. Rptr. at $185 \mathrm{n} .10$. 
right to effective assistance of counsel, and approved the trial court's procedure for establishing that Maxwell was competent to waive his rights. After a valid waiver a defendant may still argue on appeal that his legal representation was constitutionally defective for reasons unrelated to the conflict. But the burden will be on the defendant to prove that the deficiencies did not stem from the conflict. ${ }^{21}$ The court concluded that "the mere possibility of a conflict does not warrant pretrial removal of competent counsel in a criminal case over defendant's informed objection."22

Concurring in the result, Justice Kaus asserted that trial courts should not be in the role of enforcing the ethical code of the state bar. He added, however, that the majority should have condemned life story contracts more harshly in order to discourage their use. ${ }^{23}$

Chief Justice Bird both concurred and dissented. She expressed doubts as to whether Maxwell's waiver was knowing and intelligent. She agreed, though, that once a defendant is fully informed, lie can retain an attorney through a life story contract. ${ }^{24}$ She stressed that sucl contracts enable certain indigent defendants to obtain counsel of choice, a riglit she termed "one of this nation's most fundamental freedoms."25

Justice Richardson's dissent found that the court's duty to ensure effective assistance of counsel and the public's interest in the integrity of judicial proceedings override a defendant's interest in retaining a particular attorney. He condemned the contract as creating conflicts of interest that would distort the lawyer's tactical decisions, lead to the appearance of impropriety, and lessen public confidence in the judicial system. He argued that life story retainer agreements sliould be prohibited through a judicially declared rule of criminal procedure. ${ }^{26}$

\section{II}

LEGAL BACKGROUND

\section{A. The Constitutional Right to Effective Assistance of Counsel}

The sixth amendment right to assistance of counsel ${ }^{27}$ is a guaran-

21. Id. at $619 \mathrm{n} .11,639$ P.2d at $256 \mathrm{n} .11,180$ Cal. Rptr. at $185 \mathrm{n} .11$.

22. Id. at 619,639 P.2d at 255,180 Cal. Rptr. at 185 .

23. Id. at $622-23,639$ P.2d at 258,180 Cal. Rptr. at 187 (Kaus, J., concurring).

24. Id. at 623-25, 639 P.2d at 258-60, 180 Cal. Rptr. at 187-89 (Bird, C.J., concurring and dissenting).

25. Id. at $623,639 \mathrm{P} .2 \mathrm{~d}$ at $258,180 \mathrm{Cal}$. Rptr. at 187.

26. Id at 626-37, 639 P.2d at 260-66, 180 Cal. Rptr. at 189-96 (Richardson, J., dissenting).

27. The sixth amendment provides that "[i]n all criminal prosecutions, the accused shall enjoy the right . . . to have the Assistance of Counsel for his defence." U.S. CoNST. amend. VI. 
tee of effective assistance. ${ }^{28}$ The United States Supreme Court has held that this right is jeopardized when a criminal defendant is represented by an attorney who has a conflict of interest. ${ }^{29}$ Conflicts of imterest arise in a number of areas: in multiple representation, the representation of more than one defendant by the same lawyer; in successive representation, the representation of a defendant whose interests are adverse to those of a former client; and in certain fee arrangements, such as when someone other than the defendant pays the attorney. ${ }^{30}$

The United States Supreme Court has formulated the primciple that effective assistance means conflict-free counsel. In Glasser $v$. United States, ${ }^{31}$ the Supreme Court held that effective assistance of counsel means representation that is "untrammeled and unimpaired by a court order requiring that one lawyer shall simultaneously represent conflicting interests." ${ }^{32}$ In that case, the trial court had appointed Glasser's attorney (over the objections of both Glasser and his attorney) to represent a codefendant. The Supreme Court reversed Glasser's conviction, loolding that joint representation had rendered his legal assistance constitutionally defective. ${ }^{33}$

In Cuyler v. Sullivan, ${ }^{34}$ the Court held that a defendant who appeals on the basis of ineffective assistance and who failed to object to multiple representation at trial nust demonstrate "that an actual conflict of interest adversely affccted his lawyer's performance." ${ }^{35}$ But the mere possibility of conflict does not violate a defendant's sixth amendment rights, "simce a possible conflict inheres in almost every instance of multiple representation." 36

\section{B. The Limited Right to Counsel of Choice}

\section{Federal Law}

The federal courts have characterized the right to a particular attorney as qualified because certain state interests may preclude the de-

28. Glasser v. United States, 315 U.S. 60,76 (1942). Section 15 of article I of the California Constitution has also been interpreted to guarantee effective assistance. See 30 Cal. 3d at 612, 639 P.2d at 251, 180 Cal. Rptr. at 180.

29. Id at $70,76$.

30. Developments in the Law-Conficts of Interest in the Legal Profession, 94 HaRv. L. Rev. 1244, 1375-81 (1981).

31. 315 U.S. 60 (1942).

32. Id at 70 .

33. Id at 76. The Court refused, however, to reverse the co-conspirator's conviction absent a showing that he had been prejudiced. Id at 76-77. In Holloway v. Arkansas, 435 U.S. 475, 488 (1978), the Court extended Glasser by holding that automatic reversal is required "whenever a trial court improperly requires joint representation over timcly objection."

34. 446 U.S. 335 (1980).

35. Id at 348 .

36. Id 
fendant from being represented by a particular attorney. ${ }^{37}$ When these mterests are found to conflict, the courts engage in a balancing process to determine which is the weightier.

The state interests that have taken precedence over the defendant's right to particular counsel include the maintenance of ethical standards, public confidence in the integrity of the legal system, and effective administration of the courts. ${ }^{38} \mathrm{~A}$ defendant's right to choose his legal representative has been restricted in a more general sense by the courts' refusal to permit nonlawyers to act as counsel. ${ }^{39}$ Similarly, there is no right to an attorney who has been disqualified for misconduct, ${ }^{40}$ disbarred, ${ }^{41}$ or is not licensed. ${ }^{42}$ And in grand jury proceedings, when multiple witnesses wished to be represented by the same attorney, federal courts have held that a defendant's right to counsel of choice is outweighed by the public imterest in the unobstructed ferreting out of criminal activities. ${ }^{43}$

\section{California Law}

The California Supreme Court explicitly concurs that the right to counsel of choice is not absolute. ${ }^{44}$ Yet the court is far more solicitous of this right than are the federal courts. ${ }^{45}$ Indeed, the Maxwell opinion underscored the limitations placed on the trial judge's power to interfere witl the choice of counsel. ${ }^{46}$ The rationale behind its empliasis on

37. See, e.g., United States v. Hobson, 672 F.2d 825, 827 (11th Cir.), cert. denied, 103 S. Ct. 208 (1982); Willis v. United States, 614 F.2d 1200, 1202 (9th Cir. 1979); United States v. Dinitz, 538 F.2d 1214, 1219 (5th Cir. 1976), cert. denied, 429 U.S. 1104 (1977); United States v. Bragan, 499 F.2d 1376, 1379 (4th Cir. 1974).

38. See, e.g., United States v. Hobson, 672 F.2d 825, 828 (11th Cir.), cert. denied, 103 S. Ct. 208 (1982); United States v. Kitchin, 592 F.2d 900, 903 (5th Cir.), cert. denied, 444 U.S. 843 (1979).

39. United States v. Kelley, 539 F.2d 1199, 1202-03 (9th Cir.), cert. denied, 429 U.S. 963 (1976).

40. United States v. Dinitz, 538 F.2d 1214, 1221 (5th Cir. 1976), cert. denied, 429 U.S. 1104 (1977).

41. Geer, Representation of Multiple Criminal Defendants: Conficts of Interest and the Professional Responsibilities of the Defense Attorney, 62 MiNN. L. REv. 119, 160 \& n.164 (1978).

42. Id. at $160 \&$ n.163.

43. These courts noted the potential for divided loyalties on the part of the attorney and the possibility for joint stonewalling, where all witnesses exercise their fifth amendnient privilege and refuse to testify. United States v. Dolan, 570 F.2d 1177, 1182 (3d Cir. 1978); In re Grand Jury Proceedings, 428 F. Supp. 273, 276-78 (E.D. Mich. 1976).

44. People v. Crovedi, 65 Cal. 2d 199, 206, 417 P.2d 868, 873, 53 Cal. Rptr. 284, 289 (1966) (en banc).

45. See, eg., People v. Gzikowski, 32 Cal. 3d 580, 586-89, 651 P.2d 1145, 1149-51, 186 Cal. Rptr. 339, 343-45 (1982); Cannon v. Commission on Judicial Qualifications, 14 Cal. 3d 678, 697, 537 P.2d 898, 910-11, 122 Cal. Rptr. 778, 790-91 (1975) (en banc); Ingram v. Justice Court, 69 Cal. 2d 832, 840, 447 P.2d 650, 654, 73 Cal. Rptr. 410, 414 (1968) (en banc); Sinith v. Superior Court, $68 \mathrm{Cal} .2 \mathrm{~d} 547,559-60$, 440 P.2d 65, 71-72, 68 Cal. Rptr. 1, 8-9 (1968) (en banc); Morris v. Slappy, 103 S. Ct. 1610, 1616-17 (1983); United States v. Hobson, 672 F.2d 825, 828 (11th Cir. 1982).

46. $30 \mathrm{Cal} .3 \mathrm{~d}$ at 613,639 P.2d at 251-52, $180 \mathrm{Cal}$. Rptr. at 180-81. 
a defendant's choice is the larger principle that courts should not interfere with a defendant's right to decide how his defense ought to be conducted. ${ }^{47}$

Notwithstanding the importance of this right, the California courts have upheld the removal of counsel against his client's wishes when there was a competing state interest. In a criminal case, Yorn v. Superior Court ${ }^{48}$ the court of appeal upheld the pretrial removal of defendant Yorn's privately retained counsel because the lawyer had previously represented a codefendant in matters related to the case, and had also advised the victim of the crime in similar matters. The court held that "Yorn's qualified right to be represented by counsel of choice is outweighed by significant countervailing considerations." 49 ln Comden $v$. Superior Court, ${ }^{50}$ the California Supreme Court affirnied the recusal of a law firm in a civil case because of the possibility that an attorney from the firm might be called as a witness. The court found that the need to mamtain ethical standards in the legal profession was of greater importance than the client's right to counsel of choice. ${ }^{51}$

\section{Waiver}

\section{Balancing Defendant's Concerns and State Interests}

The United States Supreme Court has defined waiver as an "intentional relinquishment or abandonment of a known right or privilege."52 Waivers of constitutional rights "not only must be voluntary but must be knowing, intelligent acts done with sufficient awareness of the relevant circumstances and likely consequences." 53 Most constitutional rights associated with a criminal adjudication can be waived. For example, a defendant can waive his right to trial, to a jury, and to counsel. ${ }^{54}$ In such cases, the court deternimes whether the defendant has made a knowimg and intelligent waiver of the right in question. ${ }^{55}$

Certain rights, though relatively few, may not be waived by any defendant im any case, despite the defendant's willingness to make a knowing and intelligent waiver. ${ }^{56}$ In these cases, the courts have ruled that the competing state interests in the accuracy and fairness of judicial determinations outweigh a defendant's interest in waiving an auto-

\footnotetext{
47. Id at $609,615,639$ P.2d at 249, 253, 180 Cal. Rptr. at 178, 182 .

48. 90 Cal. App. 3d 669, 153 Cal. Rptr. 295 (1979).

49. Id at $677,153 \mathrm{Cal}$. Rptr. at 299.

50. 20 Cal. 3d 906, 576 P.2d 971, 145 Cal. Rptr. 9, cert. denied, 439 U.S. 981 (1978).

51. Id at 915,576 P.2d at 975,145 Cal. Rptr. at 13.

52. Johnson v. Zerbst, 304 U.S. 458, 464 (1938).

53. Brady v. United States, 397 U.S. 742, 748 (1970).

54. Rubin, Toward a General Theory of Waiver, 28 U.C.L.A. L. Rev. 478, $478-79$ (1981).

55. Id. at 494.

56. Id. at 493.
} 
matic appeal of a death sentence, ${ }^{57}$ the right to representation on such an appeal, ${ }^{58}$ and the requirement of attorney consent to a guilty plea in a capital crime. ${ }^{59}$

Even when a right is generally waivable, a court can refuse the waiver where there exists a significant state interest in not allowing the defendant to abandon his right. The constitutional basis for limiting waiver comes from Singer $v$. United States, ${ }^{60}$ where the United States Supreme Court stated that the "ability to waive a constitutional right does not ordmarily carry with it the right to insist upon the opposite of that right."61 The Singer Court upheld the constitutionality of a statute that permitted a defendant to waive a jury trial only when the court and prosecutor consented:

A defendant's only constitutional right concerning the method of trial is to an impartial trial by jury. We find no constitutional impediment to conditioning a waiver of this right on the consent of the prosecuting attorney and the trial judge when, if either refuses to consent, the result is simply that the defendant is subject to an impartial trial by jury-the very thing the Constitution guarantees him. ${ }^{62}$

\section{Waiver of Effective Assistance of Counsel}

Although the United States Supreme Court has stated in dicta that a defendant may waive his right to have an attorney who is free from any conflicts of interests, ${ }^{63}$ it has never held that a defendant can in all circumstances insist on representation by constitutionally defective counsel. In the absence of exphcit Supreme Court guidance on this issue, the federal appellate courts are divided on the extent to which they limit a criminal defendant's attempt to waive effective assistance of counsel. ${ }^{64}$ Some courts allow waiver of "actual," existing conflicts, ${ }^{65}$

57. Massie v. Sumner, 624 F.2d 72, 74 (9th Cir. 1980), cert. denied, 449 U.S. 1103 (1981); Commonwealth v. McKenna, 476 Pa. 428, 439-41, 383 A.2d 174, 180-81 (1978). But see Gilmore v. Utah, 429 U.S. 1012, 1014-16 (1976).

58. People v. Stanworth, 71 Cal. 2d 820, 834-35, 457 P.2d 889, 899, 80 Cal. Rptr. 49, 59 (1969) (en banc).

59. People v. Chadd, 28 Cal. 3d 739, 748-49, 621 P.2d 837, 842-43, 170 Cal. Rptr. 798, 80304, cert. denied, 452 U.S. 931 (1981).

60. 380 U.S. 24 (1965).

61. Id. at 34-35.

62. Id. at 36 .

63. Holloway v. Arkansas, 435 U.S. 475, 483 n.5 (1978) (interpreting Glasser v. United States, 315 U.S. 60, 70 (1942)). See also Cuyler v. Sullivan, 446 U.S. 335, 347 (1980).

64. Compare United States v. Garcia, 517 F.2d 272, 272-73 (5th Cir. 1975), and United States v. Reese, 699 F.2d 803, 805 (6th Cir. 1983), with United States v. Curcio, 694 F.2d 14, 26 (2d Cir. 1982). Some courts have recognized that waivers of effective assistance can also be viewed as a conflict between two constitutional rights: the right to effective assistance and the right to counsel of choice. United States v. Curcio, 694 F.2d 14, 22 \& n.8 (2d Cir. 1982).

65. See infra notes $\mathbf{1 2 6 - 3 6}$ and accompanying text. 
while others allow waiver only when the conflicts are still "potential" and have not yet arisen.

The Third Circuit takes the most restrictive approach to waiver of effective assistance. It prohibits waiver of not only actual conflicts, ${ }^{66}$ but also potential conflicts. ${ }^{67}$ In the recent case of United States $v$. Flanagan, ${ }^{68}$ the court held that while a defendant's choice should not be imtruded upon if the conflicts are highly speculative, interference with the defendant's choice is appropriate whenever conflicts are likely to materialize, even though they are only potential. The court reasoned that a defendant's power to waive a right does not give him an absolute right to have such a waiver accepted by the court. ${ }^{69}$ Nor does a defendant's right of self-representation imply an absolute right to a particular lawyer with conflicts of interest, since a defendant's decision to proceed with inultiple representation in the face of possible conflicts implicates more competing interests than a decision to represent oneself. ${ }^{70}$

In contrast, several circuits permit a defendant in multiple representation cases to make a knowing and intelligent waiver of effective assistance in order to be represented by counsel with actual conflicts of interest. In United States v. Garcia, ${ }^{71}$ the Fifth Circuit reasoned that since the Supreme Court has held that a defendant can dispense with the right to counsel altogether, he should be able to waive effective assistance of counsel. Similarly, in United States v. Reese, ${ }^{72}$ the Sixth Circuit held that even if there is an actual or strong likelihood of conflict of imterest, the defendant must be given an opportunity to waive his constitutional right to conflict-free representation.

Before permitting the waiver of either an actual or a potential conflict, the federal appellate courts use a balancing approach to ascertain whether the defendant's interests outweigh the state's interests. ${ }^{73}$

66. United States v. Dolan, 570 F.2d 1177, 1184 (3d Cir. 1978).

67. United States v. Flanagan, 679 F.2d 1072, 1076 (3d Cir. 1982), cert. granted, 103 S. Ct. 721 (1983) (No. 82-374).

68. 679 F.2d 1072, 1076 (3d Cir. 1982), cert. granted, 103 S. Ct. 721 (1983) (No. 82-374). See also United States v. Dolan, 570 F.2d 1177, 1181, 1184 (3d Cir. 1978) (judge may deny defendant's waiver when there is an "actual serious conflict of interest," or when waiver of a potential conflict cannot be intelligently made because judge, unaware of the foreseeable prejudices in the particular case, may be unable to fully inform defendant of the risks of the nultiple representation).

69. United States v. Flanagan, 679 F.2d 1072, 1076 (3d Cir. 1982), cert. granted, 103 S. Ct. 721 (1983) (No. 82-374).

70. Id. at 1076 n.5.

71. 517 F.2d 272, 277 (5th Cir. 1975).

72. 699 F.2d 803, 805 (6th Cir. 1983).

73. See, e.g., United States v. Phillips, 699 F.2d 798, 801.02 (6th Cir. 1983); United States v. Agosto, 675 F.2d 965, 970 (8th Cir. 1982); United States v. Garcia, 517 F.2d 272, 273 (Sth Cir. 1975); Lewis v. United States, 430 A.2d 528 (D.C.), cert. denied, 454 U.S. 1081 (1981). Cf. United States v. Hobson, 672 F.2d 825, 828-29 (11th Cir. 1982) (likelihood of public suspicion about lcgal system outweighed defendant's interest in particular counsel; defendant not permitted to waive 
United States v. Cunningham ${ }^{74}$ provides an illustration of this balancing. In that case, where two similarly situated defendants attempted to waive effective assistance, the court permitted one defendant (Cunningham) to keep his lawyer, and remanded for a determination of whether the other defendant would be allowed to do so. Although Cunningham's lawyer faced an ethical dilemma stemming from a previous client's expected testimony against Cunningham, the court found that Cunningham had a particularly strong interest in keeping the lawyer. For more than six years, the attorney had repeatedly disentangled Cunningham from a substantial number of investigations, prosecutions, and related hitigation. Thus, removing Cunningham's lawyer "would not inerely defeat Cunningham's abstract right to be represented by counsel of his choice; it could subject him to real prejudice in this crimmal prosecution." 75

In California, there is limited case law on the issue of waiver of effective assistance of counsel. The Maxwell court, however, read these cases as implying that the right to conflict-free counsel may be waived. ${ }^{76}$ The Maxwell court went on to hold explicitly that a criminal defendant can waive the right to effective assistance. ${ }^{77}$ Like the federal courts, the Maxwell court seemed to use a balancing approacli in determining whether to accept the waiver. ${ }^{78}$ But, as this Note argues, it failed to adequately balance all the relevant interests.

\section{Trial Court's Supervisory Powers}

The United States Supreme Court has stated that "[i]t is the judge, not counsel, who has the ultimate responsibility for the conduct of a fair and lawful trial. The judge is not a neere moderator, but is the governor of the trial for the purpose of assuring its proper conduct .....79 In California, "[a] trial court has the inherent and statutory power to imtervene on its own imitiative to inquire into any appearance of impropriety, control the proceedings to remedy the defect, and even disqualify an attorney if that appears necessary." ${ }^{80}$ The California Supreme Court has affirmed that this supervisory power mcludes the

conflict); Maynard v. Meachum, 545 F.2d 273, 278 (1st Cir. 1976) (balancing in conjunction with waiver of "full" representation in order to use "hybrid" arrangement of self-representation with lawyer ready to assume duties if necessary).

74. 672 F.2d 1064, 1070-73 (2d Cir. 1982).

75. Id. at 1071.

76. 30 Cal. $3 \mathrm{~d}$ at $619 \mathrm{n} .11,639$ P.2d at $256 \mathrm{n} .11,180$ Cal. Rptr. at $185 \mathrm{n} .11$.

77. Id. at 619,639 P.2d at 256,180 Cal. Rptr. at 185 .

78. Id at $613,616-17,619$ n.10, 639 P.2d at 252-54, 257 n.10, 180 Cal. Rptr. 182-83, 185 n.10.

79. Lakeside v. Oregon, 435 U.S. 333, $341-43$ (1978) (internal quotation marks omitted).

80. Klemm v. Superior Court, 75 Cal. App. 3d 893, 901 n.4, 142 Cal. Rptr. 509, 514 n.4 (1977). 
authority to disqualify an attorney, enabling a court to intervene during trial and reinove a defendant's attorney over the objections of the defendant. ${ }^{81}$ The Maxwell court broadened the scope of this power in recognition of the important state interests operating in a criminal trial. $^{82}$

This renoval power also extends to the pretrial setting, as federal and state courts have recognized. The Second Circuit, for example, recognized the power of the federal courts to disqualify attorneys. ${ }^{83}$ The court listed two types of situations-both of which may arise pretrial-where disqualification is appropriate: first, when an attorney's conflict of interest creates the appearance of impropriety or interferes with his independent judgment; second, when the attorney is or may be in a position to give his chent an unfair advantage by using privileged information concerning the opponent. ${ }^{84}$ The Georgia Supreme Court has similarly affirmed the pretrial disqualification of a defense attorney, ruling that multiple representation would not be permitted in capital cases. ${ }^{85}$ It reasoned that "the State, be it through the judge or prosecutor, has a responsibility under the Fourteenth Amendment to see that the defendant receives a fair trial. . . ."86

81. The California Supreme Court has affirmed this power im a number of cases. In Smith $v$. Superior Court, 68 Cal. 2d 547, 559-60, 440 P.2d 65, 72-73, 68 Cal. Rptr. 1, 9 (1968) (en banc), the court held that a trial judge possesses an inherent nonstatutory power to protect effective representation by removing a defendant's attorney during trial if the attorney exhibits "objective evidence" of physical incapacity, including illness, intoxication, or nervous breakdown. If the attorney merely makes prejudicial mistakes, however, the court is limited to less intrusive powers, with the contempt power being the "ultimate weapon" to ensure a fair trial.

The court extended its interpretation of a trial court's inherent removal power to ineffective assistance resulting from nonphysical causes in Cannon v. Commission on Judicial Qualifications, 14 Cal. 3d 678, 537 P.2d 898, 122 Cal. Rptr. 778 (1975) (en banc). It stated that if all other judicial controls have failed, a trial judge may as a last resort remove a defendant's lawyer for flagrant misconduct or imcompetence. Id. at 697, 537 P.2d at 911, 122 Cal. Rptr. at 791.

There is also statutory authority for the court's power of removal. Section 128 of the California Civil Procedure Code provides, in relevant part: "Every court shall have the power: . . . 5 . To control in furtherance of jnstice, the conduct of its ministerial officers, and of all other persons im any manner connected with a judicial proceeding before it, in every matter appertaining thereto . . . " Cal. Civ. Proc. Code $\$ 128$ (West 1982). Section 128 has been applied to criminal as well as civil cases. People v. Superior Court (Greer), 19 Cal. 3d 255, 261 n.4, 561 P.2d 1164, 1168 n.4, 137 Cal. Rptr. 476, 480 n.4 (1977).

82. In Maxwell, the court increased the number and types of actions by attorneys that can lead to recnsal. Maxwell permits a court to recuse the defense attorney when an actual conflict materializes and produces an "obviously deficient perfornance," even agaimst the wishes of a defendant who knowingly waived effective assistance of counsel. $30 \mathrm{Cal} .3 \mathrm{~d}$ at $619 \mathrm{n.10,639} \mathrm{P.2d}$ at 256 n.10, 180 Cal. Rptr. at 185 n. 10.

83. Board of Educ. v. Nyquist, 590 F.2d 1241, 1247 (2d Cir. 1979).

84. Id. at 1246.

85. Fleming v. State, 246 Ga. 90, 91-93, 270 S.E.2d 185, 187-88, cert. denied, 449 U.S. 904 (1980).

86. Id. at 91 n.3, 270 S.E.2d at 187 n.3 (citing Fitzgerald v. Estelle, 505 F.2d 1334 (5th Cir.), cert. denied, 422 U.S. 1011 (1975)). 
The California Supreme Court has also approved the exercise of the attorney removal power in a pretrial setting. ${ }^{87}$ In People v. Superior Court (Greer), ${ }^{88}$ the court upheld the pretrial removal of a district attorney over the objections of the state. Focusing on the need for prosecutorial impartiality and stressing the importance of preventing even the appearance of impropriety, the court found that the prosecutor suffered from a conflict of interest because the murder victim's mother worked in the attorney's office. ${ }^{89}$

\section{III \\ ANALYSIS}

The Maxwell court's language indicates that the interests of the state and the defendant should be weighed against each other in deciding whether to uphold the removal of Maxwell's attorney. ${ }^{90}$ Nevertheless, no true balancing of these interests occurred. Instead, the court treated the rights and interests involved as abstractions, for it did not ground its analysis in the facts of the case. First, the court did not examine the weight of Maxwell's interest in being represented by the lawyers he retained through the life story contract. Second, the court failed to analyze the nature of the conflict of interest created by the life story contract, causing it to ignore the important state interests in preventing such a contract.

\section{A. Maxwell's Interests}

\section{The Right to Counsel of Choice}

Maxwell's interest in being represented by his lawyers stems primarily from his sixth amendment right to counsel of choice. Like every defendant who retains counsel, Maxwell had a strong but nonabsolute right to proceed with the lawyers he chose to retain.

The Maxwell court emphasized the necessity of rapport and confidence between lawyer and client, and thus reasoned that counsel of choice is an important element of the fundamental constitutional right to effective assistance of counsel. ${ }^{91}$ Yet the court never defined the

87. People v. Superior Court (Greer), 19 Cal. 3d 255, 561 P.2d 1164, 137 Cal. Rptr. 476 (1977). See also Comden v. Superior Court, 20 Cal. 3d 906, 576 P.2d 971, 145 Cal. Rptr. 9 (refusing to overturn a pretrial decision removing an attorney on conflict of interest grounds because a member of his law firm was a witness in the case), cert. denied, 439 U.S. 981 (1978).

88. 19 Cal. 3d 255, 561 P.2d 1164, 137 Cal. Rptr. 476 (1977).

89. Id. at 269,561 P.2d at 1173,137 Cal. Rptr. at 485 .

90. 30 Cal. 3d at $613,616-17,619$ n.10, 639 P.2d at 252-54, 257 n.10, 180 Cal. Rptr. 181-83, 185 n. 10 .

91. Id. at 613,639 P.2d at 251, 180 Cal. Rptr. at 180. But see Morris v. Slappy, 103 S. Ct. 1610,1617 (1983) (United States Constitution does not guarantee "meaningful attorney-client relationship"). 
right to counsel of choice. Contrary to certain indications in the opinion, the right at stake in Maxwell is neither the right to the assistance of counsel, nor the right not to be represented by unwanted counsel. ${ }^{92}$ The issue is Maxwell's right to particular attorneys.

Although the court conceded that the right to a particular attorney is not absolute, ${ }^{93}$ it averred that California precedents severely restrict a judge's power to reinove a defendant's chosen attorney. These precedents define the scope of a trial court's power to interfere with a defendant's counsel of choice. In People v. Crovedi, ${ }^{94}$ the trial court was held to have unreasonably denied a request for a continuance to enable the defendant to retain a new attorney after his first attorney fell ill. Similarly, in Smith v. Superior Court, ${ }^{95}$ the supreine court ruled that the trial court had improperly dismissed defendant's counsel, over defendant's objections, because of the judge's "subjective opinion" that the attorney was incompetent. ${ }^{96}$ But in these opinions the California Supreine Court stated that a trial court need not grant an indefinite continuance $^{97}$ nor tolerate serious mistakes by counsel that might prejudice the client. ${ }^{98}$

92. The court seemed to confuse several distinct rights in its discussion and cited several precedents that are inapposite. On the one hand, the court referred to the "reasonable opportunity .. . to control the designation of [one's] lcgal representatives," a right which exists for "those defendants who have the necessary resources," id. at 613, 639 P.2d at 251, 180 Cal. Rptr. at 180, and which "extends, insofar as feasible, to the poor." Id. at 615,639 P.2d at 253, 180 Cal. Rptr. at 182. This right is no more than the sixth amendment right to retain and be represented by a lawyer. See Powell v. Alabama, 287 U.S. 45 (1932), quoted in Crooker v. California, 357 U.S. 433, 439 (1958), overnuled on other grounds by Escobedo v. lllinois, 378 U.S. 478, 492 (1964), and by Miranda v. Arizona, 384 U.S. 436, 479 n.48 (1966). See also Chandler v. Fretag, 348 U.S. 3 (1954). In Maxwell the question is not whether the defendant will receive assistance of counsel, but rather whether he will be able to be represented by the particular lawycrs he retained through the life story contract.

On the other hand, the court also mentioned a defendant's right to reject unwanted counsel. Citing Faretta v. California, 422 U.S. 806 (1975), the court observed that a defendant can disuniss his attorney and represent himself, even if the judge doubts his lcgal ability. $30 \mathrm{Cal}$. 3d at 615, 639 P.2d at 253, 180 Cal. Rptr. at 182 . The court also noted that if a defendant makes a timely request for a substitution of appointed counsel, the trial court inust at least inquire into the defendant's reasons. People v. Marsden, 2 Cal. 3d 118, 125, 465 P.2d 44, 48-49, 84 Cal. Rptr. 156, 160 (1970) (en banc). Again, the right to reject unwanted counsel is not at issue in Maxwell unless Maxwell's attorneys are the only lawyers whom Maxwell would accept.

93. 30 Cal. 3d at 613,639 P.2d at 252, 180 Cal. Rptr. at 181.

94. 65 Cal. 2d 199, 417 P.2d 868, 53 Cal. Rptr. 284 (1966).

95. 68 Cal. 2d 547, 440 P.2d 65, 68 Cal. Rptr. 1 (1968).

96. Id. at 549,440 P.2d at 66,68 Cal. Rptr. at 2. See also Cannon v. Commission on Judicial Qualifications, 14 Cal. 3d 678, 697, 537 P.2d 898, 911, 122 Cal. Rptr. 778, 791 (1975) (en banc) (involuntary removal of attorney justified upon flagrant attorney inisconduct or incompetence when all other judicial controls have failed).

97. See People v. Crovedi, 65 Cal. 2d 199, 207 n.4, 417 P.2d 868, 874 n.4, 53 Cal. Rptr. 284, 290 n.4 (1966) (en banc) (quoting People v. Dowell, 204 Cal. 109, 113, 266 P. 807, 809 (en banc), cert. dismissed, 278 U.S. 660 (1928)); People v. Douglas, 61 Cal. 2d 430, 435, 392 P.2d 964, 967, 38 Cal. Rptr. 884, 887 (1964) (en banc).

98. See Smith v. Superior Court, 68 Cal. 2d 547, 560, 440 P.2d 65, 73, 68 Cal. Rptr. 1, 9 
In its discussion of these precedents, the court seemed to imply that a court's supervisory power is more limited with respect to retained as opposed to assigned counsel, ${ }^{99}$ and thus that the court had less power to interfere with Maxwell's choice because his lawyers were retained. ${ }^{100}$ Yet this view is contrary to the Umited States Supreme Court's recent statement in Cuyler v. Sullivan" ${ }^{101}$ that "[a] proper respect for the Sixth Amendment disarms [the] contention that defendants who retain their own lawyers are entitled to less protection than defendants for whom the state appoimts counsel." 102 In Cuyler, the Court concluded that "the vital guarantee of the Sixth Amendment would stand for little if the often uninformed decision to retain a particular lawyer could reduce or forfeit the defendant's entitlement to constitutional protection." 103

\section{Objective Considerations}

The Maxwell court found the California precedents concerning the right to counsel of choice dispositive because, as will be argued later, it misjudged the nature of the conflict of interest created by the bife story contract. The court should not have looked solely to Maxwell's abstract interest ${ }^{104}$ in counsel of choice; instead, it should have looked to the particular facts of the case that might have weakened or strengthened Maxwell's interest in being represented by his attorneys.

The court thus should have adopted an approach like that taken in Harris v. Superior Court.$^{105}$ In that case, the California Supreme Court discarded a per se rule that an indigent had no right to a particular appointed attorney ${ }^{106} \mathrm{im}$ favor of a case-by-case, balancing approach. Although an indigent's "bare statement of personal preference" is still insufficient to coinpel a judge to appoint a particular lawyer, if the preference is supported by "objective considerations," and there are "no countervailing considerations of comparable weight, it is an abuse of

(1968) (en banc); supra note 82. Cf. People v. Pope, 23 Cal. 3d 412, 424, 590 P.2d 859, 865, 152 Cal. Rptr. 732, 738 (1979) (constitutional right to adequate legal assistance is denied if representation is of "lower quality than that of a reasonably conipetent attorney acting as a diligent, conscientious advocate").

99. 30 Cal. $3 \mathrm{~d}$ at $613-17,639$ P.2d at 252-54, 180 Cal. Rptr. at 181-84.

100. Even if one accepts the court's implicit dichotomy between retained and assigned counsel, Maxwell nonetheless remains an indigent whose only asset was created when the state charged him with a series of sensational crimes. The court seemed to lose sight of this fact, for it treated Maxwell like a nonindigent who could afford to retain private counsel.

101. 446 U.S. 335 (1980).

102. Id. at 344 .

103. Id.

104. See United States v. Cunninghain, 672 F.2d 1064, 1071 (2d Cir. 1982).

105. 19 Cal. 3d 786, 567 P.2d 750, 140 Cal. Rptr. 318 (1977).

106. See Drumgo v. Superior Court, 8 Cal. 3d 930, 506 P.2d 1007, 106 Cal. Rptr. 631, cert. denied, 414 U.S. 979 (1973). 
sound judicial discretion to deny the defendant's request to appoint the counsel of his preference."107

One objective consideration that would have strengthened Maxwell's interest in these particular attorneys would have been a prior legal relationship with thein. In Harris, the court recognized the inportance of prior representation as an objective factor supporting a defendant's interest in particular counsel. ${ }^{108}$ The Harris defendants had been represented by the same attorneys in previous criminal proceedings involving similar factual and legal bases as the instant case. The court held that under those circunstances the trial court had abused its discretion in refusing to appoint the lawyers. Another objective consideration that might add to a defendant's interest in representation by particular counsel would be that the attorney was especially experienced in representing defendants charged with a similar crime.

In Maxwell such factors were lacking. The one objective factor that did add to Maxwell's interest in keeping his attorneys is that the life story contract enabled him to hire private counsel. ${ }^{109}$ Thus, Maxwell's interest was probably stronger than that of a nonindigent defendant who signs a life story contract, for the pool of lawyers froin which Maxwell could hire was effectively limited to those with conflicts of interest.

Nevertheless, Maxwell's interest in being able to hire an attorney should be accorded only limited significance. Even if one is willing to assuine that retained attorneys tend to be more effective advocates than public defenders, it would seein less certain that a defendant will receive better representation from an attorney retained by means of a life story contract-with all its attendant conflicts of interest and teinptations-than he would froin a conscientious public defender.

\section{The Relevance of Maxwell's Waiver}

The court was correct in affirming that Maxwell should be required to waive his right to effective assistance of counsel. A waiver should be required in all cases where a defendant's right to effective assistance is jeopardized. After determining that Maxwell had inet the appropriate waiver standard, however, the court should have inore carefully balanced the asserted right to counsel of choice against the coinpeting state interests. The Supreine Court's holding in Singer ${ }^{110}$

107. Harris, 19 Cal. 3d at 799, 567 P.2d at 759, 140 Cal. Rptr. at 327.

108. Id. at 793, 567 P.2d at 754, 140 Cal. Rptr. at 322.

109. Maxwell may have been able to find a private attorney who would represent him pro bono. As an indigent, Maxwell would of course also have been ehigible for the services of a public defender or court-appointed lawyer.

110. 380 U.S. 24 (1965). 
suggests that a court's supervisory powers authorize it to weigh state interests against a defendant's attempted waiver. In Singer the defendant's waiver of his right to a jury trial gave him no constitutional right to a bench trial without the agreement of the court and prosecution. Similarly, a defendant who seeks to waive his right to effective assistance should have no absolute right to require a court to accept his waiver.

The rationale behind balancing state interests against an atteinpted waiver is that a defendant can waive only his personal constitutional rights; he cannot waive the state's interests in the inatter. If a waiver leads to an unjust conviction, not only has the defendant been wronged, but society's expectation of procedural regularity and fairness has been violated. Hence the state has a heavy interest in protecting a right like effective assistance of counsel that goes to the essence of due process. This interest is not diminished by a defendant's desire to waive the right. Consequently, a court should not accept a waiver of effective assistance when it cannot ensure that the defendant will receive a due process level of constitutional protection. And, as will be argued, a trial court may not be able to ensure a defendant's due process rights in a life story contract case.

Viewed from this perspective, waiver is a procedural safeguard against the uninformed relinquishınent of a right, rather than an absolute "right" to abandon a right. Accordingly, Maxwell's waiver of his right to effective assistance does not add any weight to Maxwell's interest in being represented by particular attorneys. At the same time, the waiver does not lessen the state's responsibility to ensure fair proceedings.

\section{B. The State's Interests}

\section{Public Confidence and the Integrity of the Criminal Justice System}

In his dissent Justice Richardson was right to question the majority's assertion that its opinion expressed no moral or ethical approval of life story fee contracts. ${ }^{111}$ By not recusing Maxwell's attorneys and by affirming Maxwell's waiver the court showed that it thought that the life story fee contract was constitutionally and ethically permissible.

The court should have fully evaluated the terms of the contract before allowing Maxwell to proceed with his attorneys. It could have done so without necessarily endorsing the per se rule against all life story fee contracts advocated by the dissent. ${ }^{112}$ But in effect, the court

111. 30 Cal. 3d at 636, 639 P.2d at 266, 180 Cal. Rptr. at 196 (Richardson, J., dissenting).

112. Id. at 626,639 P.2d at 260,180 Cal. Rptr. at 189. The blanket prohibition endorsed by Justice Richardson ignores significant differences among cases. First, some life story contracts 
created a strong presumption in favor of the permissibility of inost he story fee contracts. The Maxwell opinion offers trial courts no guidance as to what kind of terms must be present to trigger heightened scrutiny of these contracts.

One measure of the state interest in the ethics of the judicial system is the California Rules of Professional Conduct of the State Bar. ${ }^{113}$ Even while conceding that life story contracts "raise questions" under these Rules, the court failed to analyze whether the contract at issue in fact complied with them. ${ }^{114}$ Nonetheless, as suggested by Justice Richardson, ${ }^{115}$ a strong argument can be made that the contract violates Rule 5-101, ${ }^{116}$ which requires that the transaction and terms of the contract be "fair and reasonable" to the chent and "fully disclosed" im writing in terns reasonably understandable by the client. First, the contract makes no provision for representation during an appeal. ${ }^{17}$ Second, it does not prevent the lawyers from publishing Maxwell's story during trial or while the case is on appeal. ${ }^{118}$ Third, under the contract Maxwell agreed to waive the attorney-client privilege and

may infringe on the state's interests more than others. For example, while Maxwell's contract provided for him to share in $15 \%$ of the publication proceeds, $30 \mathrm{Cal}$. $3 \mathrm{~d}$ at $610,639 \mathrm{P} .2 \mathrm{~d}$ at 250 , 180 Cal. Rptr. at 179, Juan Corona's life story contract provided that he was not entitled to any income aside from the representation, People v. Corona, 80 Cal. App. 3d 684, 704 n.9, 145 Cal. Rptr. 894, $904 \mathrm{n.9}$ (1978). Maxwell's contract might be more against public policy because it permits a criminal defendant to benefit financially from his alleged crimes. In addition, such contracts may or may not comply with rule 5-101 of the California Rules of Professional Conduct. See Rules of Professional Conduct of the State Bar of California Rule 5-101 (1975), reprinted in 14 Cal. 3d Rules 1, Rules 19-20 (1975) [hereinafter cited as STATE BAR RuLES]. Second, one could also argue that the state imterest in preventing life story contracts is far weaker when the defendant does not face a possible death sentence. Third, the 1975 liberalization of the ethical rules governing life story contracts argues agamst a per se rejection of hife story contracts. Rule 5-101, conditionally allowing life story contracts, replaced forner rule 4, which prohibited them. See Rules of Professional. Conduct of the State Bar of California Rule 4 (1970), reprinted in $1 \mathrm{Cal}$. 3d Rules 51 , Rules 54 (1970). This change was approved by the California Suprcme Court. I B. Witkn, California Procedure Attomeys $\$ \S 190 A, 218$ (2d ed. Supp. 1983).

113. 30 Cal. $3 d$ at $616-17,639$ P.2d at 253-54, 180 Cal. Rptr. at 182-83.

114. Rule 5-101 of the California Rules of Professional Conduct provides:

A member of the State Bar shall not entcr into a busimess transaction with a chent or knowingly acquire an ownership, possessory, security, or other pecuniary imterest adverse to a client unless (1) the transaction and terns in which the member of the State Bar acquires the imterest are fair and reasonable to the client and are fully disclosed and transmitted in writing to the chent in manncr and terns which should have reasonably been understood by the cheut, (2) the chent is given a reasonable opportunity to seek the advice of independent counsel of the client's choice on the transaction, and (3) the chent consents in writing thereto.

STATE BAR Rules, supra note 112, Rule 5-101.

115. 30 Cal. 3d at 630-31, 639 P.2d at 262-63, 180 Cal. Rptr. at 192.

116. StATE BAR RuLes, supra note 112, Rule 5-101.

117. Section 1239(b) of the California Penal Code provides: "When upon any plea a judgment of death is rendered, an appeal is automatically taken by the defendant without any action by him or his counsel." CAL. PENAL CODE $\$ 1239$ (b) (West 1982).

118. The majority attempted to mitigate this problem by stating that other ethics rules would 
other privileges and rights that would prevent the literary exploitation of his life story. ${ }^{19}$ Finally, as Chief Justice Bird argued in her separate opinion, the contract poses great difficulties with respect to the Rule's full disclosure provision because the contract raises a "lost of legal problems" not easily explained to a layman. ${ }^{120}$

There are other ethical problens created by the contract. For instance, another requireinent of Rule 5-101 is that the client have a reasonable opportunity to seek the advice of independent counsel about the transaction. ${ }^{121}$ Although Maxwell was provided with teleplione numbers of local attorneys, ${ }^{122}$ it is quite likely that he could not have afforded a lawyer who would read the contract and advise him. A further ethical issue, mentioned but skirted by the majority, ${ }^{123}$ is that life story contracts may allow a criminal to profit fron his crime-a perception that surely erodes the public's confidence in the legal systen.

Finally, the contract is unfair in that Maxwell incurs a disproportionate amount of risk. The contract may cause his assistance of counsel to be ineffective at trial in ways that neither he nor the court may detect. Moreover, if Maxwell is convicted lie may face the death penalty, and on appeal he must bear the heavy burden of showing that any deficiencies in his representation did not result from the conflict of interest. $^{124}$

\section{The Duty to Ensure Fair Proceedings}

The most iniportant state interest jeopardized by life story fee contracts is that of conducting fair trials. This interest is especially weighty in criminal trials, where the civil law model of a private dispute be-

prevent the attorneys from publishing until after the criminal proceedings. $30 \mathrm{Cal} .3 \mathrm{~d}$ at $611 \mathrm{n} .1$, 639 P.2d at 250 n.1, 180 Cal. Rptr. at 179 n.1.

119. Maxwell contract, para. 37, reprinted in 101 Cal. App. 3d 736, 744-45 n.5, 161 Cal. Rptr. 849,854 n.5 (1980). At oral argument, the defense attorney conceded that this paragraph overreached and said he would not rely on it. The Richardson dissent argued that the essence of the waiver of attorney-client privilege remained. $30 \mathrm{Cal} .3 \mathrm{~d}$ at $631,639 \mathrm{P} .2 \mathrm{~d}$ at $263,180 \mathrm{Cal}$. Rptr. at 192 (Richardson, J., dissenting). But even if this hole were plugged, it simply creates another. Without the waiver of the attorney-client privilege, it is in the lawyer's financial interest to put Maxwell on the witness stand so the details of his story become public and usable. There is no evidence that this consequence was "fully disclosed" to Maxwell.

120. 30 Cal. 3d at 624, 639 P.2d at 259, 180 Cal. Rptr. at 188 (Bird, C.J., concurring and dissenting).

121. State Bar Rules, supra note 112, Rule 5-101.

122. $30 \mathrm{Cal}$. 3d at $611,639 \mathrm{P} .2 \mathrm{~d}$ at $250,180 \mathrm{Cal}$. Rptr. at 179.

123. Id. at 617 n.7, 639 P. $2 \mathrm{~d}$ at 254 n.7, 180 Cal. Rptr. at 183 n.7. Although similar legislation previously failed in California, $i d$, pending Assembly Bill 2102 would require convicted felons to set aside for 10 years for the benefit of victims any proceeds the felons earn from selling the stories of their crimes. The victims would be allowed to sue to collect restitution for 10 years. Fourteen other states have similar laws. Telephone interview with Rosa Kwong, administrative assistant to Rep. Art Agnos (D-San Francisco), the bill's sponsor (June 17, 1983).

124. 30 Cal. 3d at $619 \mathrm{n} .11,639$ P.2d at $256 \mathrm{n} .11,180$ Cal. Rptr. at $185 \mathrm{n} .11$. 
tween the parties is inapplicable. In a criminal trial the adversary is the state, whose prosecutorial power is arrayed against the individual defendant. And this interest in fair proceedings becolnes compelling when the state has accused a defendant of a crime for which lie could be executed.

In Maxwell, the California Supreme Court attempted to protect the state interest in procedural fairness by holding that a court may intervene when an actual conflict of interest materializes during trial. ${ }^{125}$ But restricting a court's power to intervene to the external manifestations of a conflict leaves this interest inadequately protected. The Maxwell court misapprehended the nature of the conflict created by the life story contract in that it incorrectly assumed that the conflict would inanifest itself in ways discernible to a trial court.

\section{a. The Actual/Potential Distinction}

In Maxwell the court held that the conflict of interest created by the life story contract was inerely "potential" rather than "actual."126 Although the court did not explicitly define its use of these terms, the opinion suggests that a conflict remains "potential" even if there are "substantial risks" that the conflict will inaterialize. ${ }^{127}$ In contrast, an "actual" conflict is one that is "inevitable." 128 The court reasoned that the life story contract would not inevitably lead to a conflict between Maxwell's legal interest and the lawyers' pecuniary interests.

The court's use of the actual/potential distinction is open to question, however. Although the meaning of these terms is often elusive in the case law, the terms seen to be used differently in two contexts. First, the distinction is used to characterize the conflicts of interest between clients, most commonly between codefendants in inultiple representation cases. ${ }^{129}$ Second, it is used in analyzing certain conflicts of interest between the lawyer and his client.

A definition of actual and potential conflicts that illustrates the way these terms are nornially used in inultiple representation cases was offered by Justice Marshall in Cuyler v. Sullivan:130

125. Id. at 619 n.10, 639 P. $2 \mathrm{~d}$ at 256 n.10, 180 Cal. Rptr. at 185 n.10.

126. Id. at 619-20, 639 P.2d at 255-56, 180 Cal. Rptr. 185.

127. Id. at $620,639 \mathrm{P} .2 \mathrm{~d}$ at $256,180 \mathrm{Cal}$. Rptr. at 185 .

128. Id. at $618 \mathrm{n} .8,639$ P.2d at $255 \mathrm{n} .8,180 \mathrm{Cal}$. Rptr. at 184 n.8.

129. See, e.g., United States v. Garcia, 517 F.2d 272 (5th Cir. 1975); Cuyler v. Sullivan, 446 U.S. $335(1980)$.

130. 446 U.S. at 356 n.3 (Marshall, J., concurring and dissenting). Justice Marshall dissented from the majority's "adversely affected" standard for the requisite showing of conflict. He reasoned that this standard was too high and that the defendant should only be required to show that an actual conflict existed at trial. Id. at 356-57. But Justice Marshall's difference with the majority does not affect the utility of his definition. 
There is a possibility of conflict, then, if the interests of the defendants may diverge at some point so as to place the attorney under inconsistent duties. There is an actual, relevant conflict of interests if, during the course of the representation the defendants' interests do diverge with respect to a material factual or legal issue or to a course of action. ${ }^{131}$

Thus, although a "possible conflict inheres in almost every instance of multiple representation," 132 one can nevertheless usefully distinguish between actual and potential conflicts in such cases. For example, a lawyer may find no actual conflict before trial when, after preliminary investigation and discussions with the defendants, he determines that their defenses will not be inconsistent. Any conflict of interest remains potential in the sense that it is contingent on the occurrence of soine event not foreseen or foreseeable at the time. But if one defendant later decides to testify agamst his codefendant, or if a witness identifies only one of the defendants, then the attorney is faced with an actual conflict of interest because the defendants' interests now diverge with respect to a material issue.

Similarly, an appellate court reviewing a claim of ineffective assistance will seek to examine the record for an "actual lapse in representation," 133 a point at which an actual conflict of interest adversely affected the lawyer's performance. ${ }^{134}$ Thus, to establisl an actual conflict a defendant must demonstrate first that some viable alternative tactic or strategy might have been pursued. Second, he must show that the alternative course was inherently in conflict with the attorney's other interests or loyalties. ${ }^{135}$

The actual/potential distimction is used differently, however, where the conflict of interest is between the lawyer's self-interest and his client rather than between clients. For instance, a public defender has been held to have an actual conflict of interest when he has a financial interest in not reportimg conflicts to the trial court. ${ }^{136}$ When the conflict is between lawyer and client, the conflict will not change from potential to actual because of some contingency that may occur at trial. Rather, a conflict is deemed actual or potential based on the extent to which the loyalties are implicitly divided from the outset.

\section{b. The Nature of the Conflict in Maxwell}

It seems that the Maxwell court misused the actual/potential dis-

131. Id. at $356 \mathrm{n.3.}$

132. Id at 348 .

133. Id. at 349 .

134. Id. at 348 .

135. Brien v. United States, 695 F.2d 10, is (1st Cir. 1982).

136. People v. Barboza, 29 Cal. 3d 375, 627 P.2d 188, 173 Cal. Rptr. 458 (1981). 
tinction. Instead of asking whether the attorneys had entered a contract that placed thein in a position of divided loyalty, the court, following the approach taken in multiple representation cases, speculated that the attorneys' financial interests would probably not lead them to neglect their professional responsibilities:

It seems not unlikely, though, that counsel's self-interests might be best served by a careful, diligent defense that avoids conviction or minimizes the penalty. A quiet strategy that succeeds may well make a better story than a flamboyant failure. Counsel's reputation, a precious professional and commercial asset, is enhanced; and the risks of professional discipline and demeaning criticism are reduced. Also, it may be commercially prudent to keep lurid facts confidential until the legal battle has ended. ${ }^{137}$

In thus labeling the conflict of interest "potential," the court was in fact speculating that the conflict would not necessarily produce deficient representation. The court was either trusting that the lawyers' representation of Maxwell would not be affected by their financial interests, or it was gambling that the lawyers would find that their financial interests coincided with Maxwell's legal needs.

Despite Maxwell's analysis, California precedent emphasizes the seriousness of the conflicts in similar attorney fee arrangements. In People v. Corona, ${ }^{138}$ the only other California life story contract case, the court of appeal stated that from the moment the lawyer entered imto the contract, he "was devoted to two inasters with conflicting imterests-he was forced to choose between his own pocketbook and the best interests of his client," 139 and thereby "assumed a position virtually adverse to his client." 140

Similarly, in People v. Barboza $a^{141}$ the California Supreme Court found an actual conflict of interest where a contract between the county and the public defender's office gave the defenders higher salaries if fewer outside attorneys were hired to handle cases when the public defenders had conflicts of interest. This arrangement created a financial imcentive for the public defenders not to report conflicts of interest. The court found that "the initial conflict here arose the moment that the public defender was appoimted .... He was immediately confronted with competing considerations - discovery of any conflicts between his client defendants versus protection of his financial selfinterest." 142

137. 30 Cal. 3d at $618 \mathrm{n} .8,639$ P.2d at $255 \mathrm{n} .8,180$ Cal. Rptr. at $184 \mathrm{n} .8$.

138. 80 Cal. App. 3d 684, 145 Cal. Rptr. 894 (1978).

139. Id. at $720,145 \mathrm{Cal}$. Rptr. at 915.

140. Id. at $721,145 \mathrm{Cal}$. Rptr. at 916.

141. 29 Cal. 3d 375, 627 P.2d 188, 173 Cal. Rptr. 458 (1981).

142. Id. at 379, 627 P.2d at 189,173 Cal. Rptr. at 459. 
Whether one calls the conflict in Maxwell actual or potential, the fact remams that the conflict seriously impedes the state's duty to ensure fair proceedings. The Maxwell court failed to give full consideration to the essential nature of this conflict: it is between the lawyer's pecuniary interests and the client's legal interests.

The United States Supreme Court recently einphasized the danger to effective representation posed by another kind of conflict imvolving a lawyer's self-interest. In Wood v. Georgia, ${ }^{143}$ the Court stated that when an attorney is paid by the defendant's employer the attorney may be "influenced in his basic strategic decisions by the interest of the employer who hired him."144 For example, the Supreme Court noted the risk that the attorney will prevent his client from obtaining leniency by discouraging him from offering testimony against his former elnployer. ${ }^{145}$ The New Jersey Supreine Court has pointed out that a lawyer may not even be aware that he is being influenced by his financial interests in protecting the fee-paying client; for "no matter what the attorney may himself think," a "direct understanding with the employer will likely weaken the attorney's resolve to serve exclusively the interest of his client." 146 Similarly, a lawyer's financial interest in the value of his chent's story may subconsciously infiuence the lawyer throughout the trial.

The Maxwell court seened to assume that if the life story contract infiuenced the attorneys' conduct, it would result in an "obviously deficient performance" that the trial court would be able to detect. However, most actions taken by an attorney at trial are easily explained away under the guise of attorney discretion or trial tactics. Normally, the attorney has the exclusive authority to determine trial tactics and strategy, ${ }^{147}$ and there are many adequate ways of handling any case. Thus, any one of a variety of tactical decisions-failing to seek a change in venue or a continuance, requiring a defendant to testify, askimg for a jury trial rather than a court trial, or encouraging a defendant to stand trial rather than plead guilty-could be inotivated either by the attorney's duty to defend his client or his desire to enhance the value of his publication rights by increasing the publicity surrounding the trial. In inultiple representation, a trial court can evaluate an attorney's tactics in relation to their effect on each defendant. But in life story contracts a court can only guess at the motivations behind the attorney's decisions. The lawyer could be pursuing his financial inter-

143. 450 U.S. $261,270-71$ (1981).

144. Id. at $271-72$.

145. Id. at 269.

146. In re Abrams, 56 N.J. 271, 278, 266 A.2d 275, 278 (1970).

147. B. Witkin, California Criminal Procedure \& 378 (1963). 
ests at the expense of his client's interests without such a course of action ever resulting in an "obviously deficient performance" that the trial court could detect.

\section{The Balancing of Interests in Maxwell}

Several factors weighed in favor of Maxwell's interest in being represented by his chosen attorneys. Maxwell, like every defendant, had the important but limited right to counsel of choice. Aside from this abstract interest, there were two factors that strengthened Maxwell's interest. First, there was the objective factor of the increased autonomy that Maxwell derived from being able to hire his own attorneys. The only attorneys whom Maxwell could hire were those he could pay witls the rights to his life story. This factor is not very weighty, however, for it is not certain that lawyers retained by uneans of a life story contract would provide more effective representation than would assigned counsel. Second, there was the subjective factor of Maxwell's confidence in his lawyers, which arguably becolnes an important consideration when one is charged with a capital crime. But this factor was offset by the special state interest in ensuring fair proceedings when a defendant faces a possible deatl sentence. Moreover, Maxwell's waiver of effective assistance did not diminisli this state interest. There were no other objective considerations adding to the weight of Maxwell's interest.

On the otlrer side of the balance, there were several state interests. First, there was the state interest in avoiding the harm to the public perception of the judicial systein caused by life story fee contracts. Second, there was tlie parallel state interest in the integrity of the judicial system. This integrity is also harmed when the judicial system acquiesces in the face of a retainer agreeinent embodying so inany ethical problems. Third, and inost importantly, there was the state interest in ensuring fair proceedings. This interest is compelling when an indigent criminal defendant faces a possible death sentence. The Maxwell court's atteinpt to protect this interest by authorizing a court to intervene when an actual conflict naterializes during trial does not adequately safeguard this state interest in fair proceedings. The conflicts created by the life story contract are such that a trial court will not necessarily be able to discern the adverse influences that the conflict is having on the lawyer's representation. For these reasons, the Maxwell court sliould have affirmed the recusal of Maxwell's attorneys.

\section{CONCLUSION}

Maxwell was the first case in which the California Supreine Court dealt witls a life story fee contract. The court failed, however, to focus 
on the terms of the contract. Consequently, the court has established a strong presumption in favor of the permissibility of life story contracts. The court provided lower courts with no guidance in determining when the terms of such a contract sliould receive stricter scrutiny.

More importantly, the court misjudged the nature of the conflicts of interest created by life story contracts. The court reasoned that such conflicts were merely "potential," and hence did not pose a significant threat to the state interest in fair proceedings. There is, lowever, both precedent and reason for treating such conflicts as actual. These conflicts are an inherent part of the agreement, for the lawyers' pecuniary interests are opposed to Maxwell's legal interests. The Maxwell court's misapprehension of the nature of the conflicts led it to underestimate the strength of the state interest in preventing life story contracts. Consequently, the court incorrectly allowed Maxwell's right to counsel of choice to outweigh the competing interests.

Helane L. Morrison*

- B.S. 1974, Northwestern University; third-year student, Boalt Hall School of Law, University of California, Berkeley. 